\title{
Adaptation to Climate Change in Developing Countries
}

\author{
Mertz, Ole; Halsnæs, Kirsten; Olesen, Jørgen E.; Rasmussen, Kjeld
}

\section{Published in:}

Environmental Management (New York)

Link to article, DOI:

$10.1007 / \mathrm{s} 00267-008-9259-3$

Publication date:

2009

Link back to DTU Orbit

Citation (APA):

Mertz, O., Halsnæs, K., Olesen, J. E., \& Rasmussen, K. (2009). Adaptation to Climate Change in Developing Countries. Environmental Management (New York), 43(5), 743-752. https://doi.org/10.1007/s00267-008-9259-3

\section{General rights}

Copyright and moral rights for the publications made accessible in the public portal are retained by the authors and/or other copyright owners and it is a condition of accessing publications that users recognise and abide by the legal requirements associated with these rights.

- Users may download and print one copy of any publication from the public portal for the purpose of private study or research.

- You may not further distribute the material or use it for any profit-making activity or commercial gain

- You may freely distribute the URL identifying the publication in the public portal

If you believe that this document breaches copyright please contact us providing details, and we will remove access to the work immediately and investigate your claim 


\section{Development and Climate Change: A Mainstreaming Approach for Assessing Economic, Social, and Environmental Impacts of Adaptation Measures}

Kirsten Halsnæs* and Sara Trærup**,***

* DTU Climate Centre, Risø National Laboratory for Sustainable Energy, Technical University of Denmark, Roskilde, Denmark

e-mail: kirsten.halsnaes@risoe.dk

** UNEP Risø Centre, Risø National Laboratory for Sustainable Energy, Technical University of Denmark, Roskilde, Denmark

e-mail: sara.traerup@risoe.dk

*** Department of Geography \& Geology, University of Copenhagen, Copenhagen, Denmark

\section{Abstract}

The paper introduces the so-called climate change approach, where vulnerability and adaptation measures are assessed in the context of general development policy objectives. The approach is based on the application of a limited set of indicators. These indicators are selected as representatives of focal development policy objectives, and a stepwise approach for addressing climate change impacts, development linkages, and the economic, social and environmental dimensions related to vulnerability and adaptation are introduced. Within this context it is illustrated using three case studies how development policy indicators in practice can be used to assess climate change impacts and adaptation measures based on three case studies, namely a road project in flood prone areas of Mozambique, rainwater harvesting in the agricultural sector in Tanzania and malaria protection in Tanzania. The conclusions of the paper confirm that climate risks can be reduced at relatively low costs, but the uncertainty is still remaining about some of the wider development impacts of implementing climate change adaptation measures.

Keywords: Climate change, Mainstreaming, Sustainable development 


\section{Introduction}

Climate change is a global environmental problem and international studies predominantly have addressed climate change from an environmental policy perspective. However, emerging literature recognizes that climate change variability, extreme events and structural changes have major impacts on economic, social, and human living conditions as well as on natural systems. This implies, in developing countries, that key goals related to poverty reduction, water, food, energy, education and health are critically influenced by climate change, and that adaptation measures therefore should be tackled in the context of development policies.

The strong relationship between climate change and development is also recognized by IPCC in its Fourth Assessment report by stating that "The distribution of impacts and vulnerabilities is still considered to be uneven, and low-latitude, less-developed areas are generally at greatest risk due to both higher sensitivity and lower adaptive capacity; but there is new evidence that vulnerability to climate change is also highly variable within countries, including developed countries” (IPCC 2007, page 781).

Existing efforts on climate change and development linkages include activities by the International Institute for Environment and Development (IIED), which has worked on mainstreaming climate change and on disaster risk reduction (Yamin and Huq 2005, Huq and others 2006), and the World Resources Institute which, in a recent methodological case study analysis, has addressed how adaptation can be framed in the context of development (McGray and others 2007). OECD is similarly in a process of developing guidelines for how development assistance can take climate change into consideration, and this work has been supported by several technical adaptation studies (Agrawal 2005). 
Recognizing the importance of linking development and climate change, the so-called mainstreaming approach aims at evaluating climate change policies in the context of general development goals. The objective of this paper is to introduce how a mainstreaming approach can be operationalised, and to demonstrate how it can be used in relation to case studies in Mozambique and Tanzania.

It is important to recognize that applying a mainstreaming approach opens a new set of issues on how to compare the use of scarce development funds for climate change adaptation with alternative uses. In many cases climate change adaptation can go hand in hand with other development activities in such a way that the activities jointly support the same goals. In other cases, adding an element of adaptation to development policies imposes significant costs that can imply delaying out other development investments from which a discussion about different priorities can emerge. In practice however, it can be expected that some part of the additional costs from including climate change adaptation can be paid by international funds or bilateral donors, in which case there is no national conflict between spending resources on development programmes and climate change adaptation.

There are several implications of applying a mainstreaming approach to the evaluation of climate change adaptation policies:

- Climate change is addressed as a development problem and aspects like human welfare and its various social and human dimensions are linked to environmental issues.

- The issue moves into the domain of multiple sectors including agriculture, water, health, energy, and infrastructure.

- The current impacts of climate extremes and disasters and their links to development are the starting points for assessing future climate change impacts. 
- There is a need for linking climate change impact data and development statistics, which, given uncertainties and data limitations, complicates adaptation studies.

The next section presents an analytical framework that can be used to assess climate change in a context of development analyses.

\section{Analytical Framework}

The idea of the mainstreaming approach is to assess climate change impacts and vulnerabilities in the context of development. Figure 1 below illustrates a structure that can be used to assess the relationship between development, climate change, and adaptation options.

\section{FIGURE 1 HERE}

The figure is structured in five columns. Starting from the left the first column represents the Climate System that can be characterized by a set of climate variables such as temperature, precipitation, and humidity $\left(\mathrm{x}_{1}, \ldots . \mathrm{x}_{\mathrm{n}}\right)$. The second, third and fourth columns illustrate Development without climate change (column 2), with climate change (column 3), and with both climate change and adaptation policies (column 3). Development in these three columns can be characterized by a set of variables $\left(\mathrm{y}_{1}, \ldots \ldots . . \mathrm{y}_{\mathrm{n}}\right)$ that can be understood as focal indicators of various economic, social and environmental development targets considered to reflect key priorities. Finally, column 4 represents adaptation strategies that can be characterized by a set of variables $\left(\mathrm{z}_{1}, \ldots \ldots . \mathrm{z}_{\mathrm{n}}\right)$.

It is important to recognize that all the elements and analytical steps included in the figure are surrounded by significant uncertainties and data limitations. This includes establishing climate information at a detailed regional level to linking climate data and socio-economic factors. 
The vertical dimension of the diagram represents the time dimension. Starting at the left top corner of the diagram, the starting point assesses how the present climate influences the development today. Similarly, future development stages are influenced by the climate and are termed Development State $\mathbf{A}$ if the climate is unchanged, and Development State $\mathbf{B}$ if the climate is changed. Studies of climate change in the context of development (mainstreaming) include an assessment of the links between the climate and development objectives at present and in the future. This assessment can suggest implementation of adaptation options and results in the achievement of a new Development State $\mathbf{C}$.

It should be recognized that it is a very demanding task to establish quantitative data for assessment of the relationship between climate and specific development dimensions (or development goals) even if this is done at a detailed level for specific activities, like farming at provincial level. The complexities arrive from several factors including limited availability of long time series of climate data that can be linked to farming output and incomplete understandings of the many factors that play together in production functions in agriculture including climatic factors, land, labour, machinery, seeds, irrigation and education.

In a more simple way it can be said that the aim of mainstreaming assessments is to ensure that current, as well as future development policies, are well adapted to the climate and this can imply that some adaptation options are recommended. This way the mainstreaming approach aims at assessing the relationship between the climate and development in general, without giving specific consideration to distinguishing anthropogenic climate change impacts and vulnerabilities from climate vulnerability of development policies per se. This is different from approaches such as those applied by GEF funding, where the assessment of incremental costs of adaptation to anthropogenic climate change is a focal point. 
The fact that many economic activities at present are not well adapted to climatic conditions is complicating. Examples are rain feed agriculture in dry areas where irrigation facilities are not available, or livelihoods in low lying areas that suffer from flooding. In such cases

mainstreaming climate assessment can reveal that a future development state like $\mathbf{C}$ (Figure 1) can be better off in terms of development indicators than a future development state like $\mathbf{A}$ which, by definition, assumes that no climate change is occurring. This can be the case when it is assumed that some current maladaptations to the current climate, as well as future negative climate change impacts, are overcome in state $\mathbf{E}$ and adaptation policies in such a case sometimes can render development benefits larger than the costs of implementing the options.

Based on the structure given in Figure 1, a stepwise mainstreaming approach for assessing adaptation can include the following analytical elements:

Element 1: Climate Conditions, Variability and Future Changes

The initial basis for the assessment is to establish data about the present climate, its variability, and the potential changes over time. Time and geographical resolution should be rather detailed in order to facilitate the use in relation to sectoral and local assessments.

\section{Element 2: Selection of Development Indicators}

The next step is to select development indicators that reflect key economic, social and environmental policy objectives and climate sensitivities.

Element 3: Assessing the Relationship between Climate Variables and Development Indicators related to Specific Activities 
Element 1 and Element 2 then can be combined in order to understand the sensitivity of development policies to the climate. Preferably the links should be based on statistical data and should provide a basis for projecting the impacts of future climate changes.

\section{Element 4: Adaptation Options}

Finally the assessment can identify adaptation options that can be used to make current and future development states better adapted to climate change, in order to measure the costs and development impacts of implementing these options.

The stepwise analytical approach is applied to the assessment of case examples of climate change vulnerability and adaptation from Mozambique and Tanzania, in order to shed more light on the individual elements.

\section{Definition of Climate, Development and Policy Variables}

Integrated climate change and development assessments can address a number of policy issues related to a short list of well-defined policy variables, which can be used to point to key development and climate issues as introduced in Figure 1 above. The major focus of mainstreaming studies is to meet specific development objectives and therefore the climate impacts should be assessed in relation to how they influence key development policy goals. The very pragmatic approach recommended here suggests selecting a limited set of indicators considered to represent key areas where climate-development linkages can be addressed. These areas will depend on sectoral focus but can include economic areas in terms of costs, investments and employment; social areas in terms of income to poor families, education and 
health; and environmental areas in terms of different pollutants. Table 1 gives an overview of how the economic, social and environmental areas can be measured.

\section{TABLE 1 HERE}

In practice it will not be possible to cover all the aspects included in Table 1, hence a few areas, particularly relevant for the focal study area, must be selected. In an agricultural study from Bangladesh (Mirza 2002) it is seen how the different elements in the mainstreaming approach can be used The study assessed possible future changes in the magnitude and return periods of floods and related crop damages as a consequence of climate change under various warming scenarios. Historical data from 1965 - 1992 was applied to estimate future flood occurrence for three large rivers in Bangladesh and climate scenarios were developed in order to model climate conditions, variability and changes (see element 1 above). The analysis demonstrated significant changes in the mean annual peak discharges of the rivers for various warming scenarios. Crop damages were chosen as development indicators (element 2), and the relationship between combined peak discharges of the three rivers and amount of crop damage was established (element 3), assuming crop damage during a monsoon to be a function of flood volume. The results were subsequently used to estimate flood impacts on crop yields in the affected areas, employment in the agricultural sector and agricultural GDP contribution. Finally capacity building in the agricultural sector was mentioned as an adaptation option (element 4) to reduce crop damages, but no further detailed analysis on this measure was conducted.

\section{Mainstreaming Studies for Case Studies in Mozambique and Tanzania}

The climate change mainstreaming approach is illustrated based on three case studies for Mozambique and Tanzania and the previously introduced step wise analytical approach is used 
to assess climate change, development impacts and potential adaptation measures. Due to data limitations the analyses are indicative of potential impacts and adaptation measures rather than accurate information about all relevant aspects and it has in practice primarily been possible to include a limited number of indicators of the direct costs and benefits of implementing specific measures. The limitations of these economic parameters will be highlighted in relation to the different case examples and this will be followed up by a discussion about what the implication of addressing a wider range of development indicators could have been. The case examples are infrastructure planning in Mozambique, rainwater harvesting in Tanzania and Malaria protection in Tanzania. An overview of the examples is given in Table 2.

\section{TABLE 2 HERE}

The focus of the Mozambique case study is on how roads can be made flooding proof and the additional resources required relative to the value of improved market access. The cases examined for Tanzania are rainwater harvesting for management of irrigation water in order to cope with expected increased precipitation variability with climate change, and malaria treatment to cope with current and expected increasing future risks with higher temperatures in the highlands.

\section{Example 1: Infrastructure planning in Mozambique}

The Limpopo Basin in southern Mozambique is an area extremely at risk to flooding. This was already seen in the 2000 flooding where more than 500 hundred people died, 200,000 people were forced into refugee camps and impacts on infrastructure caused serious damages to the roads and bridges, preventing normal traffic along the main road for more than 6 months (INGC 
2003). The basin is the second largest in Mozambique and its dams have very little storage capacity for regulating water flow into the lowlands, meaning that downstream areas experience sudden increases in water levels and currents during periods of heavy rains. The flooding is difficult to regulate since it depends on cross border river systems. In this way the lowlands are facing flooding risks and the risks are further accelerated by climate change impacts. This example focuses on road infrastructure and resistance of roads to flooding in the southern part of Limpopo which is highly populated. The stepwise mainstreaming approach is applied as follows

\section{Element 1 Climate Conditions, Variability and Future Changes}

Climate projections and regional hydrologic models for southern Africa, including Mozambique, indicate that climate change can lead to significant changes in timing and magnitude of water run-off which can consequently increase the frequency and scale of flooding. Recent climate statistics show that the average total regional precipitation has decreased for southern Africa, including Mozambique, but there has been a statistically significant increase in the regionally averaged daily precipitation intensity for the period 1961 - 2000 (New and others 2006).

Flooding in the Limpopo Basin is often caused by heavy rainfall in South Africa, Zimbabwe and Botswana (Vaz 2000). The observed trends of increased rainfall intensity can therefore be expected in the future to lead to more floods in the Limpopo Basin. Results based on the IPCC's SRES emission scenarios for river run-off using the HadCM3 climate models indicate a significant increase in run-off for 2050 (Arnell 2003, 2004).

\section{Element 2: Selection of Development Indicators}

The expected increase in magnitude and intensity of floods will affect rural livelihoods, health, agriculture and roads in the Limpopo Basin. Due to data availability the current case study is 
only addressing direct impacts on roads, but a more qualitative description of other impact areas are subsequently given. In addition to reconstruction and maintenance costs, the flooding will also have indirect costs related to disrupted market access when the roads are out of function.

Element 3: Assessing the Relationship between Climate Variables and Development Indicators related to Specific Activities

Disrupted market access in flooding periods has shown to imply limited food supplies to and from markets as well as price increases and this becomes more pertinent when the demand in flooding periods increases due to loss of crops and livestock. For example, the flood in Mozambique in 2000 entailed a 70 percent price increase for maize (INGC and others 2003).

A number of broader development impacts of the Limpopo flooding in 2000 are shown in Table 3 and these numbers subsequently are used to discuss the costs of flooding events as such.

\section{TABLE 3 HERE}

The 2000 flooding in Limpopo displaced almost 300,000 people and included 78 villages as seen in Table 3. The damage on houses resulted in reconstruction costs of over 40 million US\$ and 4 million US\$ for schools. During the 2000 flood the affected areas experienced food price increases of up to 70 percent for a duration of two to three months, where after prices decreased to normal levels (INGC and others 2003) with consequences for consumption expenditures. Based on the assumption that the average monthly consumption per person in the area is estimated to be 229 US\$ (GoM 2001), a 70 percent price increase would result in increasing expenditures for consumption of about 390 US\$ per person during the flooding period. People 
may not be able to economically respond to the higher costs of consumption and therefore they may adjust to lower consumption levels.

\section{Step 4 Adaptation Options}

The adaptation options considered in this section focuses on the roads as an example of a key impact area and does not cover all impacts on houses, villages and other assets. Potential adaptation measures against flooding include construction of roads with drainage systems, increased road levels, alternative routes, stronger foundation and bridges. These options can be integrated in construction and rehabilitation plans based on risk assessments of future climate variability and change.

The cost considerations of adaptation to climate change of road infrastructure in the Limpopo Basin is further based on data from a rehabilitation and maintenance project for a $20 \mathrm{~km}$ road in Limpopo (World Bank 2000, 2001) that is planned to be implemented over ten years. This project is used as a baseline case. The project assumes design profiles to include future higher traffic levels and greater resistance to flood damages based on historical flooding trends, and it is expected that this construction will reduce losses from flooding by 50 percent. In addition the baseline assumes flood loss exposure to be reduced by 50 percent. This reduction is due to an integrated minor drainage systems adjusted to accommodate a 1-in-20 year flood and profiles for major structures, e.g. bridges, to accommodate a 1-in-40 years flood.

Future climate change has not been taken into consideration in this project. Taking this into consideration would imply that an assessment of the construction and maintenance costs with and without climate change is conducted. The magnitude of such costs can be understood based on a study from the Federate States of Micronesia (ADB 2005) that calculated the construction 
costs of a road with and without climate change adaptation options integrated. The upfront costs of the road increase if climate change adaptation is considered but will be offset by lower maintenance costs and the net costs consequently will be lower after 15 years. Over 50 years total construction, maintenance and repair costs of the road without climate change adaptation measures showed to be 56.5 percent above the costs for a road with adaptation measures included. Table 4 illustrates the costs of two road scenarios with and without climate change adaptation measures which are calculated based on assumptions on economic estimates from the Micronesia study by ADB (2005).

\section{TABLE 4 HERE}

In addition to the net cost savings of the road project with adaptation, the improved road will also facilitate easier access for emergency and relief in flooding periods and will reduce periods with inadequate market access. Furthermore more rapid emergency response will potentially decrease the number of incidences of disease. The 2000 flood showed that where roads were more rapidly reconstructed, the areas stabilized and returned to normal conditions faster compared to areas which were isolated for longer periods.

\section{Example 2: Rain water harvesting in Tanzania}

Climate change is predicted to extend the period between rainfalls in Tanzania (Hulme and others 2001). During dry seasons, dry spells with almost no rain are expected to become more common while the number of spells with high intensity precipitation seems to increase during the rainy season. Crop yields will most likely decrease if water is not stored during the rainy season even without climate change. Taking climate change into consideration, water availability will be even scarcer during the dry season (which is longer and dryer) and the 
demand for water storage is extended compared to a situation without climate change. Potential adaptation options include increased water storage capacity and improved water management. If such adaptation measures are integrated into the planning process of the agricultural season, improved water management can alleviate the effect from decreased rainfall during the growing season.

The economic assumptions in this example are based on a case study by Kadigi and others (2003) about water availability for irrigation of rice paddies and the impacts on crop yields, in Dodoma region, Tanzania. The Dodoma climate is characterized by a long dry season lasting between late April and early December and a short single rain season occurring during the remaining months. The average rainfall for the Dodoma Region is $574 \mathrm{~mm}$ and about 85 percent of this falls in the months between December and April (Tanzania Meteorological Agency 2006). Rainfall is rather unpredictable in frequency and amount and climate change is expected to increase this uncertainty. The unreliable rainfall imposes a pattern of risk aversion in agriculture and is a serious constraint on present efforts to improve crop yields. As it can be seen from Figure 2 the annual variability has been particularly large in 2001 and 2002.

\section{FIGURE 2 HERE}

The following step wise approach is considering alternative water availability scenarios under present conditions and these alternatives are used as a basis for assessing the impacts of water scarcity in dry seasons under future climate variability and change. The water availability data in this study corresponds to less rainfall variability than is seen under climate change. Scaling up this data as done in the current example would most likely give a relatively low estimate of the impacts. 
Element 1 Climate Conditions, Variability and Future Changes

Precipitation is predicted to increase with 5-30 percent during the rainy season and decrease with 5-10 percent during dry months for year 2020 in Tanzania and especially the interior part of the country will experience temperature increases and longer dry periods (Hulme and others 2001 and Clark and others 2003).

\section{Element 2: Selection of Development Indicators}

Changes in precipitation will influence water availability and will extend the demand for larger water storage if precipitation is concentrated over a shorter period. This will influence crop yield and this again influences other indicators such as income, agricultural employment and nutritional status in the household.

Element 3: Assessing the Relationship between Climate Variables and Development Indicators related to Specific Activities

Water shortage limits the quantity and variety of crops and also has a negative influence on the possibilities for enhanced crop or livestock production in relation to emerging markets. Water shortage, therefore, presents a key barrier to poverty reduction in poor rural areas. Crop yields generally depend on temperature and precipitation patterns. The relationships between temperatures, precipitation patterns and crop yields have been established in a number of studies, e.g. for the US, but the relationship is very context specific both in terms of crops, geographical location and specific climate conditions (Rosenzweig and others 2001, Mohamed and others 2002, and Meertens and others 1999) and there is therefore some uncertainty about 
the relationship in Tanzania. More frequent droughts and decreased water availability during dry months will shorten the growing season and reduce crop yields. Nonetheless, few studies have been done for Tanzania and the existing studies do not integrate climate change considerations or take into account increased variability in precipitation patterns (Kadigi and others 2004, Senkondo and others 2004 and Hatibu and others 2006). The existing studies follow the historical trends in rainfall variability and do not consider or prepare for increased rainfall variability or demand for extended water storage capacity.

\section{Element 4 Adaptation Options}

Potential adaptation measures to changes in rainfall patterns for crops include rain water storage for irrigation, adjustment of planting dates, changes in fertilization, introduction of new crop varieties and location, application of conservation tillage, and reduced utilization of marginal lands.

The current example focuses on expansion of water storage capacity based on rain water harvesting for paddy rice production as the adaptation option which, can be implemented by farmers with low cost. Paddy rice can not be grown without irrigation and rain water harvesting systems are therefore already applied today. However, up-scaling efforts are needed in order to cease the effect from longer and dryer periods between rains. The example assesses the costs and benefits of an extended rainwater harvesting scheme. This is compared to a baseline case where historical rainfall trends are assumed. In both climate scenarios rainfall in Dodoma is assumed to decrease by 10 percent during the dry season and increase with 20 percent during the rainy season. Total rainfall is thereby assumed to increase, but the dry period has become dryer and the rain season more wet. This is illustrated in Table 5. In addition the rain water harvesting schemes are assumed to last beyond year 2020. Table 5 illustrates that total amount of rainfall is 
likely to increase but there will be larger variation between the rainfall in the dry and the wet season.

\section{TABLE 5 HERE}

The expanded water storage capacity is obtained from an extension of an existing excavated bounded basin, a method of run-off utilization, management and storage of water for paddy rice production. The expansion is constructed by digging to a depth of 0.2 to 0.5 meter and the scooped soil is used to build a bund around the field perimeter (Lazaro and others 2000). Construction costs are amortized over a life time period of ten years assuming 10 percent annual maintenance cost. The only construction inputs are land and labour. Cost of land is assumed to be zero while labour is assumed to be provided by family members having low opportunity costs, especially if the work is carried out during slack season. The cost of hired labour used in peak seasons for sowing and harvesting is valued based on opportunity cost of labour used in a study of rain water harvesting in Tanzania (Senkondo and others 2004).

In order to compare the situations without and with adaptation, a gross margin analysis is carried out to assess costs and benefits of the intervention. Precipitation patterns and temperatures are assumed to be equal in the two situations. The results are depicted in Tables 6 and 7.

\section{TABLE 6 \& 7 HERE}

A comparison of the cost-benefit analysis without and with adaptation options (Tables 6 and 7) shows that there is an increase in the average gross margins from US\$ 94 per hectare to US\$ 221 in the first year with adaptation and this gain increases in the subsequent years since all the construction costs fall in year 1 , see also Table 8 . The extended rainwater harvesting system 
implies a very large increase in the yield from $352 \mathrm{~kg} / \mathrm{ha}$ without adaptation to $586 \mathrm{~kg} / \mathrm{ha}$ with adaptation. The net present value (NPV) for the total result of the adaptation investment is calculated from the net benefits of adaptation and is shown in Table 8 .

\section{TABLE 8 HERE}

The analysis clearly demonstrates that the returns to the investment, in extended water storage capacity under climate change exceed the returns of the baseline situation with no climate adaptation measures. Hence the example shows that a relatively simple adaptation intervention, such as rain water harvesting, is beneficial in terms of economic return as well as of increased food security in the dry seasons. Furthermore this adaptation option has many positive sideimpacts in terms of improved health conditions from decreased malnutrition, which is also a key vulnerability factor in relation to Malaria.

\section{Example 3: Malaria prevention in Tanzania}

Malaria is a key contributor to mortality and morbidity in Tanzania and as much as 93 percent of the population in Tanzania is at risk of malaria (WHO 2003a). People at risk live in areas with relatively stable malaria transmission or in areas where malaria risk is seasonal and less predictable because of either altitude or rainfall patterns. In areas with seasonal risk of malaria, the risk is likely to change due to changes in rainfall and temperatures imposed by climate change and are expected to become more widespread throughout the year. The following case example will focus on malaria prevention as well as vulnerabilities and adaptation measures related to malaria using the previously introduced stepwise approach. 
Referring to Example 2, the East African highlands are highly susceptible to predicted climate variability and changes. These include expected increases in precipitation by year 2020 with 530 percent during rainy season and decreases with 5-10 percent during the dry months and prolonged dry seasons due to increased climate variability and change (Hulme and others 2001 and Clark and others 2003). Daily temperatures are predicted to increase by an average of $0.5^{\circ} \mathrm{C}$ per decade through the $20^{\text {th }}$ century (Hulme and others 2001).

\section{Element 2: Selection of Development Indicators}

The development indicators applied in this case example are the number of malaria incidences and mortality. There is also a number of other impacts of malaria, many other health issues are indirectly linked to malaria and malaria indices have huge welfare costs for individuals and causes loss of income. Repeated malaria infections make young children more susceptible to other common childhood diseases, such as diarrhoea and respiratory infections and severe anaemia with high rate of mortality (WHO 2003b). Moreover, malaria infections in pregnant women frequently lead to a low child birth weight and this is a major risk factor in the first months of a child's life.

Element 3: Assessing the Relationship between Climate Variables and Development Indicators related to Specific Activities

It is expected that the distribution of malaria will be extended into new areas of the highlands and in some areas the season for malaria will be expanded with climate change. The incidence and distribution of malaria are affected by several factors including temperatures and precipitation patterns. Increases in the number of malaria incidences have been attributed to increased climate variability in several studies (WHO 2003a, Cox and others 1999, Zhou and 
others 2004, Wandiga and others 2006, Abeko and others 2003, and Githeko \& Ndegwa 2001). Even small seasonal changes may create large adjustments in number of malaria incidences (Fisman 2007). Based on this, it can be expected that increased temperatures can create malaria conditions in new highland areas which until now, due to low temperatures, have been unsuitable as malaria breeding grounds.

There are numerous development implications of malaria. These can be measured through direct and indirect costs (WHO 2003b). The direct costs involve personal expenditures such as purchase of bed nets and insecticides for treatment of the nets, mosquito coils, mosquito repellent lotions, aerosol sprays, anti-malarial drugs, transportation to health care facilities and the necessary supportive costs for the patient and caretaker. Indirect costs refer to productivity losses associated with morbidity and mortality. In the case of morbidity it involves the wage loss or value of output associated with lost working time for each case and the costs of caretakers, school absenteeism and delayed investment opportunities.

In the case of mortality, lost income can be estimated by calculating the capitalized value of future lifetime earnings that would have been gained by those who died prematurely from malaria. Children who survive malaria may suffer long-term consequences of the infection since repeated episodes of fever and illness reduce appetite and restrict play, social interactions and educational opportunities, thereby contributing to poor development.

The most vulnerable to malaria are mainly children under five years and pregnant women. This example concentrates in the group of children below five years of age. 
The use of malaria prevention is currently inadequate and an extension of preventive measures is expected to lead to considerable benefits. With extended use of malaria preventive measures as an adaptation option, a moderate level of malaria incidences can be obtained with consequential savings in lives lost and avoided morbidity together with substantial savings in treatment costs.

There are several adaptation measures, which can be applied to malaria prevention. One option is residential house spraying which involves treating all interior walls and ceilings with an insecticide, which is effective against mosquitoes that favour indoor resting before or after feeding. However, spraying has been abandoned or curtailed in many countries due to disillusionment over eradication results and to concerns over safety and environmental impacts. Administrative, managerial and financial constraints have also been an implementation barrier. Other options are malaria vaccine and medical prevention with chemoprophylaxis that is a presumptive intermittent treatment. However, this is not perceived as appropriate to the whole population. Lastly, insecticide treated bed nets (ITNs) is an option, which have shown to be an effective, feasible and economic attractive measure in reducing mortality and morbidity from malaria (Goodman and others 2001, Hanson and others 2003, Lengeler 2004, Mueller 2008 and Mulligan 2008).

ITNs effectively provide a reduction in transmission intensity as they prevent mosquito bites and shorten the mosquito's life span, thereby reducing transmission (Breman and others 2006). The beneficial impacts of large-scale ITN programs have been demonstrated in Tanzania (Abdulla and others 2001, Armstrong-Schellenberg and others 2001a and WHO 2003a) and recently in Eritrea (Graves 2008) and expansion of ITN coverage is chosen as the adaptation measure in this example. A social marketing and distribution programme of ITNs in Tanzania (ArmstrongSchellenberg and others 2001b) has shown to reduce mortality among children under five with 
20 percent and morbidity with 50 percent. Applying a 100 percent coverage ITN programme in Tanzania to this group of children could lead to 15,000 averted deaths and 3,195,000 averted cases according to the National Malaria Medium Term Strategic Plan 2002 - 2007, Ministry of Health in Tanzania (URT 2003) and a case study on the costs and consequences of a social marketing approach to malaria control in Tanzania in two rural districts by Hanson and others (2003) (see Table 9).

\section{TABLE 9 HERE}

In order to evaluate benefits two different metrics are applied: disability-adjusted life years (DALYs) and value of statistical life (VOSL). DALYs are calculated as the sum of years of life lost due to premature mortality and the years lost due to disability for incident cases of the health condition. VOSL broadly measures the individual willingness-to-pay to reduce the risk of death and to small changes in mortality risks. Both metrics rely on economic valuation techniques and are associated with uncertainty due to lack of market prices. The valuation includes benefits associated with an improvement in health as well as health care costs and expenditures saved due to the improvement in health. It has been argued that the willingness to pay for improved health may only include the welfare impacts due to illness and can thereby be criticized for discrimination against the poor who have less ability to pay due to their relatively low incomes. These limitations should be kept in mind in the economic valuation of the current example. The economic assumptions applied are shown in Table 10.

\section{TABLE 10 HERE}

The benefits of the two scenarios that are shown in Table 9 are subsequently given in Table 11 and 12. The benefits include direct cost savings by reduced treatment costs and indirect cost 
savings in terms of DALYs and VOSLs respectively. With a 20 percent effectiveness of ITN's on saved lives and 50 percent avoided cases, the project will result in additionally about 800,000 avoided cases and 3,750 extra saved lives. The benefit and cost estimates of the programme are calculated based on assumptions from Markandya (1998) and Hanson and others (2003) on the economic value of a VOSL on 87,970 US\$ and of a DALY on 57 US\$. Life expectancies are 54.2 years at birth and 58.6 years at the age of 3. Calculation of VOSL is based on the ratio of real per capita GDP in Tanzania and adjusted to GDP in the US. By using real GDP it will take into account the purchasing power of the country, in this particular case Tanzania. Furthermore, it is assumed that insecticide lasts for 12 months. Malaria treatment costs are calculated based on a study by Jowett and Miller (2005) on treatment costs in Tanzania. Finally the treatment costs are discounted by thirty-five percent to account for non-compliance and smaller child doses.

\section{TABLE 11 HERE}

The comparison of gross margins, using DALY, from scenarios with and without adaptation in Table 11, show that the net benefit from the enhanced ITN programme is about US\$ 330,449 per year. Using the method of VOSL, net benefits are about 329,887,500 per year, which is substantially higher than the result with application of DALYs. This is shown in Table 12.

\section{TABLE 12 HERE}

The above figures suggest that there potentially are considerable benefits associated with upscaling the use of ITNs in prevention, particularly if climate change will imply significant 
acceleration of malaria incidences. Expanded ITN distribution could in this case be a very attractive adaptation option.

\section{Conclusions}

The most important lesson learned from this paper is that adaptation is closely interlinked with focal development areas such as infrastructure, agriculture and health, and there is a large potential for integrating climate adaptation measures into already existing and on-going projects and planning efforts. In the case examples examined, integrating climate change adaptation could be done with a low cost.

Climate change mainstreaming has been addressed in a pragmatic way in the paper using a short list of sustainable development indicators to evaluate economic, social, and environmental dimensions of climate change adaptation. The approach is stepwise and starts with modelling of climate conditions, variability and change, which subsequently are linked to development policies and indicators. This is followed by an identification of adaptation measures and assessment of these compared with unmitigated climate change impacts. The methodological approach is further illustrated in relation to three case studies from Mozambique and Tanzania.

The Mozambique example is related to infrastructure planning where existing and future highways can be damaged by increasing magnitude and intensity of floods. The damages will increase maintenance costs and can cause temporary disruptions on the roads. The highways could potentially be less vulnerable to climate change if adaptation measures, in terms of 
drainage systems, stronger foundations and bridges and alternative routes, were taken into consideration. Based on experiences from previous flooding events in 2002 in Mozambique and internationally available data on adaptation measures, it is shown that there could be significant benefits associated with more climate safe road design.

Rain water harvesting for agricultural irrigation have been considered as a case example for Tanzania, based on the expectation that agriculture in many parts of the country will need increased irrigation with climate change. The development impacts of enhanced rainwater harvesting capacity for rice paddy production are considered based on a previous study from the Dodoma region of Tanzania. Climate change was not taken into consideration in this study however, an extrapolation of the cost and benefit results of enhanced irrigation measures in this case suggest that the rainwater harvesting systems are very effective in supporting crop yields and economic performance.

Increased malaria protection in Tanzania through increased distribution of bed nets has been considered as an adaptation measure against an expected increase of the incidence of malaria associated with climate change. The costs of malaria net distribution and information programmes are measured against avoided treatment costs and reduced sickness and mortality, and it is concluded that almost 4000 lives could be saved and 800.000 cases could be averted annually by distributing 800,000 additional net to cover the whole population in Tanzania. Such a program is considered to be very economic attractive and the net benefits were assessed to be 300,000 USD per year. Despite the potential large benefits of mainstreaming climate adaptation into malaria programmes, it should be noted that malaria protection planning in a climate context is as complex as in general malaria planning and there is no easy solutions in establishing not only knowledge but also utilization of interventions such as ITNs. 
The approach in this way illustrates how sustainable development indicators and climate change can be linked, and quantitative information is provided about key linkages and impacts. A number of broader social impacts could be covered in more detail than it has been possible in the current case examples, and this could potentially further strengthen the argument that climate change adaptation measures could be important measures in reducing the vulnerability of the poor. This is the case because climate risks could be reduced for a relatively low cost in the examples, and because not coping with these could further enhance vulnerabilities in terms of

poor health conditions for woman and children, weak infrastructure and flooding risks, and crop losses due to high variability of precipitation.

\section{Acknowledgements}

The authors of this paper have been contracted by the Danish Ministry of Foreign Affairs to assist in the implementation of the Danish Climate and Development Action Programme/Danida. This paper is inspired by the experiences gained by the authors through implementation of the Action Programme and do not represent the official views of the Danish Ministry of Foreign Affairs/Danida. 


\section{References}

Abdulla S, Armstrong-Schellenberg J, Nathan R, Mukasa O, Marchant T, Smith T, Lengeler C (2001) Impact of malaria morbidity of a programme supplying insecticide treated nets in children aged under 2 years in Tanzania: community cross sectional study. BMJ Journals 322(3): 270 - 273.

Abeku T, van Oortmarssen G, Borsboom GJ, de Vlas SJ, Habbema JDF (2003) Spatial and temporal variations of malaria epidemic risk in Ethiopia: factors involved and implications. Acta Tropica 87(3):331 - 340

ADB (2005) Climate Proofing: A Risk-based Approach to Adaptation. Pacific Studies Series. Asian Development Bank.

Agrawal S (ed) (2005) Bridge over troubled waters: linking climate change and development. Organisation for Economic Cooperation and Development (OECD), Paris, France

Armstrong-Schellenberg J, Abdulla S, Minja H, Nathan R, Mukasa O, Marchant T, Mponda H, Kikumbih N, Lyimo E, Manchester T, Tanner M, Lengeler C (2001a) KINET: a social marketing programme of treated nets and net treatment for malaria control in Tanzania, with evaluation of child health and long-term survival. Transactions of the Royal Society of Tropical Medicine and Hygiene 93(3): 225 - 31

Armstrong-Schellenberg J, Abdulla S, Nathan R, Mukasa O, Marchant TJ, Kikumbih N (2001b) Effect of Large-Scale Social Marketing of Insecticide-Treated Nets on Child Survival in Rural Tanzania. Lancet 357(9264): 1241 - 1247 
Arnell N (2003) Effects of IPCC’s SRES scenarios on river run-off: a global perspective. Hydrology and Earth System Sciences 7(5): 619 - 641

Arnell N (2004) Climate change and global water resources: SRES emissions and socioeconomic scenarios. Global Environmental Change 14: 31 - 52

Clark CO, Webster PJ, Cole JE (2003) Interdecadal Variability of the Relationship between the Indian Ocean Zonal Mode and East African Coastal Rainfall Anomalies. Journal of Climate 16: $548-554$

Boko M, Niang I, Nyong A, Vogel C, Githeko A, Medany M, Osman-Elasha B, Tabo R, Yanda P (2007) Africa. In: Parry ML, Canziani OF, Palutikof JP, van der Linden PJ, Hanson CE (eds) Climate Change 2007: Impacts, Adaptation and Vulnerability. Contribution of Working Group II to the Fourth Assessment Report of the Intergovernmental Panel on Climate Change. Cambridge University Press, Cambridge, UK

Breman JG, Mills A, Snow RW, Mulligan J, Lengeler C, Mendis K, Sharp B, Morel C, Marchesini P, White NJ, Steketee RW, Doumbo OK (2006) Conquering Malaria. Chapter 21. In: Jamison DT, Breman JG, Measham AR, Alleyne G, Claeson M, Evans DB, Jha P, Mills A, Musgrove P (eds) Disease Control Priorities in Developing Countries. Second edition. Oxford University Press and The World Bank. Washington, USA

Cox J, Craig M, Le Sueur D, Sharp B (1999) Mapping malaria risk in the highlands of Africa. Mara/HIMAL technical report. WHO

Fisman DN (2007) Seasonality of Infectious Diseases. Annual Review of Public Health 28:12743 
Githeko AK, Ndegwa W (2001) Predicting malaria epidemics using climate data in Kenyan highlands: a tool for decision makers. Global Change \& Human Health 2: 54 - 63

Goodman CA, Mnzava AEP, Dlamini SS, Sharp BL, Mthembu BJ, Gumede JK (2001)

Comparison of the cost and cost-effectiveness of insecticide-treated bednets and residual housespraying in KwaZulu-Natal, South Africa. Tropical Medicine and International Health 6(4): 280 $-295$

GoM (2001) Action Plan for the reduction of absolute poverty (2001 - 2005) (PARPA). Government of Mozambique. Maputo, Mozambique

Graves, PM, Osgood SE, Thomson MC, Sereke K, Araia A, Zerom M, Ceccato P, Bell M, del Corral J, Ghebreselassie S, Brantly EP, Ghebremeske T (2008) Effectiveness of malaria control during changing climate conditions in Eritrea, 1998-2003. Tropical Medicine and International Health Volume 13(2): 218 - 228

Hanson K, Kikumbih N, Armstrong Schellenberg J, Mponda H, Nathan R, Lake S, Mills A, Tanner M, Lengeler C (2003) Cost-effectiveness of social marketing of insecticide treated nets for malaria control in United Republic of Tanzania. Bulletin of World Health Organization 81(4): 269 - 276

Hatibu N, Mutabazi K, Senkondo EM, Msangi ASK (2006) Economics of rainwater harvesting for crop enterprises in semi-arid areas of East Africa. Agricultural Water Management 80: 74 86

Hulme M, Doherty R, Ngara T, New M, Lister D (2001) African Climate Change: 1900 - 2100. Climate Research 17(2): 145 - 168 
Huq S, Reid H, Murray LA (2006) Climate Change and Development Links. Gatekeeper Series 123. International Institute for Environment and Development (IIED). London, UK. 24pp INGC (2003) Limpopo Disaster Atlas. University of Eduardo Mondlane - Department of Geography, FEWS NET MIND. Maputo, Mozambique

IPCC (2007) Climate Change 2007: Impacts, Adaptation and Vulnerability. Contribution of Working Group II to the Fourth Assessment Report of the Intergovernmental Panel on Climate Change. Parry ML, Canziani OF, Palutikof JP, van der Linden PJ, Hanson CE (eds). Cambridge University Press, Cambridge, UK, 976pp

Jowett M, Miller NJ (2005) The financial burden of malaria in Tanzania: implications for future government policy. The International Journal of Health Planning and Management 20(1):67 84

Kadigi RMJ (2003) Rice production economics at local and national levels: the case study of Usangu Plains in Tanzania. Report for RIPARWIN Project, DFID-KAR Project No. R8064. Soil-Water Management Research Group, Sokoine University of Agriculture, Tanzania Kadigi RMJ, Kashaigili JJ, Mdoe N (2004) The economics of irrigated paddy in Usangu Basin in Tanzania: water utilization, productivity, income and livelihood implications. Physics and Chemistry of the Earth 29(15- 18): 1091 - 1100

Lazaro EA, Senkondo EM, Kajiro GJ (2000) Information technology and socio-economic aspects in the planning of RWH. In: Hatibu N, Mahoo HF (eds) Rainwater harvesting for natural resources management: a planning guide for Tanzania. Swedish International Development Cooperation Agency (Sida). RELMA technical handbook series 22: 87 - 144 
Lengeler C (2004) Insecticide-treated bed nets and curtains for preventing malaria. The

Cochrane Database of Systematic Reviews 2004, Issue 2

Markandya (1998) The indirect costs and benefits of greenhouse gas limitations. UNEP Risoe

Centre. Roskilde, Denmark

McGray H, Hammill A, Bradley R, Schipper EL, Parry J (2007) Weathering the Storm: Options for Framing Adaptation and Development. World Resources Institute. Washington, USA

Meertens HCC, Ndege LJ, Lupeja PM (1999) The cultivation of rainfed, lowland rice in Sukumaland, Tanzania. Agriculture, Ecosystems and Environment 76: 31-45

Mirza MMQ (2002) Global Warming and Changes in the Probability of Occurrence of Floods in Bangladesh and Implications. Global Environmental Change 12(2): 127 - 138

Mohamed AB, Van Duivenbooden N, Abdoussallam S (2002) Impact of climate change on agricultural production in the Sahel - part 1. Methodological approach and case study for millet in Niger. Climatic Change 54: 327-348

Mueller DH, Wiseman V, Bakusa D, Morgah K, Daré A, Tchamdja P (2008) Cost-effectiveness analysis of insecticide-treated net distribution as part of the Togo Integrated Child Health Campaign. Malaria Journal 7: 73

Mulligan J, Yukich J, Hanson K (2008) Costs and effects of the Tanzanian national voucher scheme for insecticide-treated nets. Malaria Journal 7: 32

New M, Hewitson B, Stephenson DB, Tsiga A, Kruger A, Manhique A, Gomez B, Coelho CAS, Ntiki Masisi D, Kululanga E, Mbambalala E, Adesina F, Saleh H, Kanyanga J, Adosi J, Bulane 
L, Fortunata L, Mdoka ML, Lajoie R (2006) Evidence of trends in daily climate extremes over southern and west Africa. Journal of geophysical research 111: D14102

Rosenzweig C, Tubiellob FN, Goldbergb R, Millsc E, Bloomfieldd J (2001) Increased crop damage in the US from excess precipitation under climate change. Global Environmental Change 12: 197-202

Senkondo EMM, Msangi ASK, Xavery P, Lazaro EA, Hatibu N (2004) Profitability of rainwater harvesting for agricultural production in selected semi-arid areas of Tanzania. Journal of Applied Irrigation Science 39(1): 65 - 81

Tanzania Meteorological Agency (2006) Data on Monthly Rainfall Totals in Millimeters. Dar es Salaam, Tanzania

URT (2003) National Malaria Medium Term Strategic Plan 2001 - 2007. Ministry of Health, Government of Tanzania, Dar es Salaam, Tanzania

Vaz AC (2000) Coping with floods - the experience of Mozambique. Paper presented at 1st WARFSA/ WaterNet Symposium: Sustainable Use of Water Resources, 1-2 November 2000, Maputo, Mozambique

Wandiga SO, Opondo M, Olago D, Githeko A, Githui F, Marshall M, Downs T, Opere A, Yanda PZ, Kangalawe R, Kabumbuli R, Kirumira E, Kathuri J, Apindi E, Olaka L, Ogallo L, Mugambi P, Sigalla R, Nanyunja R, Baguma T, Achola P (2006) Vulnerability to climate induced highland malaria in East Africa. AIACC Working Paper No 25 
World Bank (2000) Technical annex for a proposed credit of SDR 22.4 million (US\$ 30 million equivalent) to the Republic of Mozambique for a flood recovery project. Report No. T- 7370MOZ. Washington, USA

World Bank (2001) Project appraisal document on a proposed credit in the amount of SDR 127.4 million (US\$ 162.0 million equivalent) to the Republic of Mozambique for phase 1 of the roads and bridges management and maintenance program (APL - phase 1). Report No: 21839. Washington, USA

WHO (2003a) The Africa Malaria Report 2003. World Health Organization/UNICEF. Geneva, Switzerland

WHO (2003b) Documentation on the socio-economic impact of malaria epidemics in Africa. World Health Organization. Geneva, Switzerland

Yamin F Huq S (eds) (2005) Vulnerability, Adaptation and Climate Disasters. IDS Bulletin 36(4)

Zhou G, Minakawa N, Githeko AK, Yan G (2004) Association between climate variability and malaria epidemics in the East African highlands. Ecology 101(8): 2375 - 2380 


\begin{tabular}{|l|l|l|}
\hline Impacts Areas & Indicators & Measurement Standards \\
\hline Economic & $\begin{array}{l}\text { Costs } \\
\text { Employment } \\
\text { Investments }\end{array}$ & $\begin{array}{l}\text { Cost measures } \\
\text { Economic surplus/profit } \\
\text { Capital requirements } \\
\text { Jobs }\end{array}$ \\
\hline Social & $\begin{array}{l}\text { Income } \\
\text { Education } \\
\text { Health }\end{array}$ & $\begin{array}{l}\text { Income generation and distribution } \\
\text { Time available for education } \\
\text { Number of people with different diseases }\end{array}$ \\
\hline Environmental & $\begin{array}{l}\text { Climate change } \\
\text { Local pollution }\end{array}$ & $\begin{array}{l}\text { GHG emissions } \\
\text { Local pollutants } \\
\text { Ecosystem degradation }\end{array}$ \\
& & \\
\hline
\end{tabular}

Table 1. Examples of development policy dimensions and measurement standards that can be applied to the assessment of development-climate linkages 


\begin{tabular}{|c|c|c|c|}
\hline Example & Climate Change Impacts & $\begin{array}{l}\text { Development Impacts } \\
\text { Considered }\end{array}$ & Adaptation Options \\
\hline $\begin{array}{l}\text { Infrastructure } \\
\text { planning }\end{array}$ & $\begin{array}{l}\text { Highways in Mozambique are } \\
\text { expected to be damaged by } \\
\text { increasing magnitude and } \\
\text { intensity of floods. The } \\
\text { damages will increase } \\
\text { maintenance costs and can } \\
\text { cause temporary disruptions }\end{array}$ & $\begin{array}{ll}- & \text { Maintenance costs } \\
- & \text { Impacts of disrupted } \\
\text { market access at local } \\
\text { and regional level }\end{array}$ & $\begin{array}{ll}- & \text { Road drainage systems } \\
\text { - } & \text { Stronger foundation and } \\
\text { bridges } \\
\text { - } & \text { Alternative routes }\end{array}$ \\
\hline $\begin{array}{l}\text { Rain water } \\
\text { harvesting in } \\
\text { agriculture }\end{array}$ & $\begin{array}{l}\text { Climate change is expected to } \\
\text { influence the magnitude and } \\
\text { time distribution of } \\
\text { precipitation in Tanzania, and } \\
\text { agriculture therefore can be } \\
\text { increasingly dependent on } \\
\text { irrigation }\end{array}$ & $\begin{array}{ll}\text { - } & \text { Crop yields } \\
\text { - } & \text { Employment } \\
\text { - } & \text { Income }\end{array}$ & $\begin{array}{l}\text { Increased water storage } \\
\text { capacity for irrigation } \\
\text { purpose }\end{array}$ \\
\hline $\begin{array}{l}\text { Malaria } \\
\text { prevention }\end{array}$ & $\begin{array}{l}\text { Increased temperatures and } \\
\text { changed precipitation patterns } \\
\text { that is expected to increase } \\
\text { number of malaria incidences }\end{array}$ & $\begin{array}{ll}\text { - } & \text { Treatment costs } \\
\text { - } & \text { “Sickness” } \\
\text { - } & \text { Mortality }\end{array}$ & $\begin{array}{ll} & \text { Malaria bed nets and } \\
\text { information campaigns }\end{array}$ \\
\hline
\end{tabular}

Table 2. Overview of Climate change and Development Impacts of Case Studies in Mozambique and Tanzania 


\begin{tabular}{|l|r|l|l|l|l|}
\hline Indicator & Unit & $\begin{array}{l}\text { Total cost of } \\
\text { damage } \\
\text { per unit, US\$ }\end{array}$ & $\begin{array}{l}\text { Total cost of } \\
\text { damage } \\
\text { Mill US\$ }\end{array}$ & $\begin{array}{l}\text { lost of } \\
\text { reconstruction } \\
\text { per unit, US\$ }\end{array}$ & $\begin{array}{l}\text { Total cost of } \\
\text { reconstruction } \\
\text { Mill US\$ }\end{array}$ \\
\hline Number of people displaced & 295,500 & & & & \\
\hline Number of villages displaced & 78 & & & & \\
\hline Number of houses damaged & 47,000 & 580 & 27.0 & 872 & 41.0 \\
\hline Number of schools damaged & 60 & 37,400 & 2.2 & 37,400 & 4.0 \\
\hline
\end{tabular}

Table 3. Flood Impacts in the Limpopo Basin, year 2000. Data computed from INGC and others (2003) and World Bank (2000) 


\begin{tabular}{|l|r|r|}
\hline \multirow{2}{*}{} & \multicolumn{2}{|c|}{ Costs per km (US\$) } \\
\cline { 2 - 3 } & Without adaptation measures & With adaptation measures \\
\hline Cost of construction & 190,000 & \\
Road surface & 96,970 & 190,000 \\
Drainage work & $\mathbf{2 8 7 , 1 2 1}$ & 174,393 \\
Total costs of construction & & $\mathbf{3 6 4 , 5 4 5}$ \\
$\quad$ Incremental cost & $\mathbf{1 , 1 8 2 , 2 7 3}$ & $\mathbf{7 7 , 4 2 4}$ \\
\hline $\begin{array}{l}\text { Total cost of construction, maintenance, } \\
\text { and repair costs }\end{array}$ & & $\mathbf{7 5 5 , 4 5 5}$ \\
$\quad \begin{array}{l}\text { Net benefit of mainstreaming } \\
\text { adaptation measures }\end{array}$ & & 426,819 \\
\hline
\end{tabular}

Table 4. Costs of road construction with and without mainstreaming of climate change adaptation measures. Total cost of construction, maintenance, and repair costs shows Net Present Values over 50 years, with a $3 \%$ discount rate. The table is computed based on economic value assumptions from ADB (2005) 


\begin{tabular}{|c|c|c|}
\hline & $\begin{array}{l}\text { Rainfall in millimetres, } \\
\text { historical trend } \\
(1974-2004)\end{array}$ & $\begin{array}{l}\text { Rainfall in millimetres, } \\
\text { expected future trend } \\
(2020)\end{array}$ \\
\hline Total average rainfall, rain season & 488 & 586 \\
\hline Total average rainfall, dry season & 86 & 77 \\
\hline Total rainfall & 574 & 663 \\
\hline
\end{tabular}

Table 5. Historical and expected future rainfall in Dodoma region. Based on Tanzania Meteorological Agency (2006). 


\begin{tabular}{|c|c|c|c|c|c|c|c|c|}
\hline & & & \multicolumn{6}{|c|}{ Total value per year US\$ (2000 prices) } \\
\hline & Units & Price/unit & Year 1 & Year 2 & Year 3 & $\cdots$ & Year 9 & Year 10 \\
\hline \multicolumn{9}{|l|}{ Revenue: } \\
\hline Yield (kg/ha) & 1,800 & 0.20 & 351.56 & 351.56 & 351.56 & -do- & 351.56 & 351.56 \\
\hline $\begin{array}{l}\text { Total Revenue (US\$/ha)(not } \\
\text { discounted) }\end{array}$ & & & 351.56 & 351.56 & 351.56 & -do- & 351.56 & 351.56 \\
\hline $\begin{array}{l}\text { Costs: } \\
\text { Maintenance cost of existing } \\
\text { water storage }\end{array}$ & \multicolumn{8}{|c|}{ Costs: } \\
\hline Plot renting (US\$/ha) & 1 & 37.50 & 37.50 & 37.50 & 37.50 & -do- & 37.50 & 37.50 \\
\hline Seeds (kg/ha) & 24 & 0.25 & 6.00 & 6.00 & 6.00 & -do- & 6.00 & 6.00 \\
\hline Fertilizer (bags/ha) & 2 & 18.75 & 18.75 & 18.75 & 18.75 & -do- & 18.75 & 18.75 \\
\hline Tractor hiring charge(US\$/ha) & 1 & 37.50 & 37.50 & 37.50 & 37.50 & -do- & 37.50 & 37.50 \\
\hline Hired labor (days/ha) & 39 & 1.25 & 48.75 & 48.75 & 48.75 & -do- & 48.75 & 48.75 \\
\hline Family labor (days/ha) & 183 & 0.33 & 61.08 & 61.08 & 61.08 & -do- & 61.08 & 61.08 \\
\hline Bags and twine & 10 & 0.88 & 8.80 & 8.80 & 8.80 & -do- & 8.80 & 8.80 \\
\hline Transport & & & 10.00 & 10.00 & 10.00 & -do- & 10.00 & 10.00 \\
\hline $\begin{array}{l}\text { Total Costs (US\$/ha)(not } \\
\text { discounted) }\end{array}$ & & & 257.76 & 257.76 & 257.76 & -do- & 257.76 & 257.76 \\
\hline $\begin{array}{l}\text { Gross Margin (US\$/ha) (not } \\
\text { discounted) }\end{array}$ & & & 94.00 & 94.00 & 94.00 & -do- & 94.00 & 94.00 \\
\hline Average farm/plot size & 0.7 & & & & & & & \\
\hline $\begin{array}{l}\text { Gross return to an average plot } \\
\text { (Tsh) }\end{array}$ & & & 66.00 & 66.00 & 66.00 & -do- & 66.00 & 66.00 \\
\hline $\begin{array}{l}\text { Estimated annual volumetric water } \\
\text { demand (use) ( } \mathrm{m}^{3} \text { per ha) }\end{array}$ & 13731 & & & & & & & \\
\hline $\begin{array}{l}\text { Estimated annual volumetric water } \\
\text { demand for the average farm size } \\
\text { of } 0.7 \text { ha }\left(\mathrm{m}^{3}\right)\end{array}$ & 9611.7 & & & & & & & \\
\hline $\begin{array}{l}\text { Productivity (value) of water } \\
\left(\mathrm{Kg} / \mathrm{m}^{3}\right)\end{array}$ & 0.13 & & & & & & & \\
\hline $\begin{array}{l}\text { Productivity (value) of water } \\
\left(\mathrm{Tsh} / \mathrm{m}^{3}\right)\end{array}$ & & 0.20 & 0.03 & 0.03 & 0.03 & -do- & 0.03 & 0.03 \\
\hline
\end{tabular}

Table 6: Costs and benefits of rice paddy production with existing rainwater harvesting system, assuming that future climate change has not been taken into consideration with adaptation measures

The calculations are based on data from Lazaro and others (2000) and Kadigi (2003) 


\begin{tabular}{|c|c|c|c|c|c|c|c|c|}
\hline & & & \multicolumn{6}{|c|}{ Total value per year US\$ (2000 prices) } \\
\hline & Units & Price/unit & Year 1 & Year 2 & Year 3 & $\ldots$ & Year 9 & Year 10 \\
\hline \multicolumn{9}{|l|}{ Revenue: } \\
\hline $\begin{array}{l}\text { Yield (kg/ha) } \\
\text { Total Revenue (US\$/ha) (not } \\
\text { discounted) }\end{array}$ & 3,000 & 156.25 & $\begin{array}{l}585.94 \\
585.94\end{array}$ & $\begin{array}{l}585.94 \\
585.94\end{array}$ & $\begin{array}{l}585.94 \\
585.94\end{array}$ & $\begin{array}{l}585.94 \\
585.94\end{array}$ & $\begin{array}{l}585.94 \\
585.94\end{array}$ & $\begin{array}{l}585.94 \\
585.94\end{array}$ \\
\hline $\begin{array}{l}\text { Costs: } \\
\text { Investment cost, water storage } \\
\text { (man days, family labor) } \\
\text { Maintenance cost of water } \\
\text { storage }\end{array}$ & 320 & 0.33 & $\begin{array}{l}106.80 \\
10.68\end{array}$ & 10.68 & 10.68 & -do- & 10.68 & 10.68 \\
\hline Plot renting (US\$/ha) & 1 & 37.50 & 37.50 & 37.50 & 37.50 & -do- & 37.50 & 37.50 \\
\hline Seeds (kg/ha) & 24 & 0.25 & 6.00 & 6.00 & 6.00 & -do- & 6.00 & 6.00 \\
\hline Fertilizer (bags/ha) & 2 & 18.75 & 18.75 & 18.75 & 18.75 & -do- & 18.75 & 18.75 \\
\hline Tractor hiring charge(US\$/ha) & 1 & 37.50 & 37.50 & 37.50 & 37.50 & -do- & 37.50 & 37.50 \\
\hline Hired labor (days/ha) & 39 & 1.25 & 48.75 & 48.75 & 48.75 & -do- & 48.75 & 48.75 \\
\hline Family labor (days/ha) & 183 & 0.33 & 61.08 & 61.08 & 61.08 & -do- & 61.08 & 61.08 \\
\hline Bags and twine & 10 & 0.88 & 8.80 & 8.80 & 8.80 & -do- & 8.80 & 8.80 \\
\hline $\begin{array}{l}\text { Transport } \\
\text { Total Costs (US\$/ha)(not } \\
\text { discounted) }\end{array}$ & & & $\begin{array}{l}10.00 \\
364.56 \\
\end{array}$ & $\begin{array}{l}10.00 \\
257.76 \\
\end{array}$ & $\begin{array}{l}10.00 \\
257.76\end{array}$ & $\begin{array}{l}\text {-do- } \\
\text {-do- }\end{array}$ & $\begin{array}{l}10.00 \\
257.76\end{array}$ & $\begin{array}{l}10.00 \\
257.76\end{array}$ \\
\hline $\begin{array}{l}\text { Gross Margin (US\$/ha) (not } \\
\text { discounted) }\end{array}$ & & & 221.38 & 328.18 & 328.18 & -do- & 328.18 & 328.18 \\
\hline $\begin{array}{l}\text { Average farm/plot size } \\
\text { Gross return to an average } \\
\text { farm(Tsh) } \\
\text { Estimated annual volumetric water } \\
\text { demand (use) ( } \mathrm{m}^{3} \text { per ha) } \\
\text { Estimated annual volumetric water } \\
\text { demand for the average farm size } \\
\text { of } 0.7 \text { ha }\left(\mathrm{m}^{3}\right) \\
\text { Productivity (value) of water } \\
\left(\text { Kg/m } \mathrm{m}^{3}\right) \\
\text { Productivity (value) of water } \\
\left(\mathrm{US} \$ / \mathrm{m}^{3}\right)\end{array}$ & $\begin{array}{l}13731 \\
9611.7 \\
0.22\end{array}$ & 0.20 & 154.97 & 229.73 & 183,781 & -do- & 183,781 & 183,781 \\
\hline
\end{tabular}

Table 7: Costs and benefits of rice paddy production with expansion of an existing rainwater harvesting system, assuming future climate change and adaptation measures. The calculations are based on data from Lazaro and others (2000) and Kadigi (2003) 


\begin{tabular}{rrrrrr}
\hline & & \multicolumn{4}{c}{ Discounted Net Benefits } \\
\hline Year & Benefits & Costs & Net Benefits & $\mathbf{7 \%}$ & $\mathbf{1 5 \%}$ \\
\hline 1 & 234.38 & 105.48 & 128.90 & 120.46 & 112.08 \\
\hline 2 & 234.38 & -1.32 & 235.70 & 205.87 & 178.22 \\
\hline 3 & 234.38 & -1.32 & 235.70 & 192.40 & 154.97 \\
\hline 4 & 234.38 & -1.32 & 235.70 & 179.81 & 134.76 \\
\hline 5 & 234.38 & -1.32 & 235.70 & 168.05 & 117.18 \\
\hline 6 & 234.38 & -1.32 & 235.70 & 157.05 & 101.90 \\
\hline 7 & 234.38 & -1.32 & 235.70 & 146.78 & 88.61 \\
\hline 8 & 234.38 & -1.32 & 235.70 & 137.18 & 77.05 \\
\hline 9 & 234.38 & -1.32 & 235.70 & 128.20 & 67.00 \\
\hline 10 & 234.38 & -1.32 & 235.70 & 119.82 & 58.26 \\
\hline $\begin{array}{r}\text { NPV, } \\
\text { US\$ }\end{array}$ & & & & $\mathbf{1 , 5 5 5 . 6 1}$ & $\mathbf{1 , 0 9 0 . 0 3}$ \\
\hline
\end{tabular}

Table 8: The costs and benefits of implementing extended rainwater harvesting as an adaptation measure for rice paddy production, NPV's in US\$ 2000 


\begin{tabular}{|c|c|c|}
\hline & $\begin{array}{l}\text { Without Extended ITN } \\
\text { Coverage }\end{array}$ & $\begin{array}{l}\text { With Extended ITN } \\
\text { Coverage }\end{array}$ \\
\hline Children exposed to stable malaria transmission & $7,100,000$ & $7,100,000$ \\
\hline Children with ITNs & $5,325,000$ & $7,100,000$ \\
\hline No. of distributed ITNs & $2,759,067$ & $3,678,756$ \\
\hline No. averted deaths & 11,250 & 15,000 \\
\hline No. averted cases per year & $2,396,250$ & $3,195,000$ \\
\hline No. of averted DALYs & 310,300 & 413,733 \\
\hline
\end{tabular}

Table 9. Overview of indicators related to malaria based on Hanson and others (2003) and URT (2003) 


\begin{tabular}{|ll|}
\hline & Value in US\$ (2000) \\
\hline Benefit per DALY avoided & 57 \\
VOSL per person & 87,970 \\
Cost of treatment per treatment & 0.747 \\
ITN per net (including distribution & 6.7 \\
costs) & \\
\hline
\end{tabular}

Table 10. Economic assumptions 


\begin{tabular}{|c|c|c|c|c|c|c|}
\hline & \multicolumn{3}{|c|}{ Without adaptation } & \multicolumn{3}{|c|}{ With adaptation } \\
\hline & $\begin{array}{l}\text { Value per unit } \\
\text { US\$ (2000) }\end{array}$ & Unit & $\begin{array}{l}\text { Total value } \\
\text { US\$ (2000) }\end{array}$ & $\begin{array}{l}\text { Value per unit } \\
\text { US\$ (2000) }\end{array}$ & Unit & $\begin{array}{l}\text { Total value } \\
\text { US\$ (2000) }\end{array}$ \\
\hline Benefits & & & & & & \\
\hline $\begin{array}{l}\text { DALY } \\
\text { averted }\end{array}$ & 57 & 310,300 & $17,687,100$ & 57 & 413,733 & $23,582,800$ \\
\hline $\begin{array}{l}\text { Saved cost of } \\
\text { treatment }\end{array}$ & 0.747 & $2,396,250$ & $1,789,999$ & 0.747 & $3,195,000$ & 2,386,665 \\
\hline Costs & & & & & & \\
\hline $\begin{array}{l}\text { Distribution } \\
\text { of ITN }\end{array}$ & 6.7 & $2,759,067$ & & 6.7 & $3,678,756$ & $24,647,668$ \\
\hline Gross margins & & & 991,347 & & & $1,321,797$ \\
\hline
\end{tabular}

Table 11. Baseline scenario without adaptation and scenario with adaptation, using DALY 


\begin{tabular}{|c|c|c|c|c|c|c|}
\hline & \multicolumn{3}{|c|}{ Without adaptation } & \multicolumn{3}{|l|}{ With adaptation } \\
\hline & $\begin{array}{l}\text { Value per unit } \\
\text { US\$ (2000) }\end{array}$ & Unit & $\begin{array}{l}\text { Total value } \\
\text { US\$ (2000) } \\
\end{array}$ & $\begin{array}{l}\text { Value per unit } \\
\text { US\$ (2000) }\end{array}$ & Unit & $\begin{array}{l}\text { Total value } \\
\text { US\$ (2000) }\end{array}$ \\
\hline \multicolumn{7}{|l|}{ Benefits } \\
\hline Saved lives & 87.970 & 11,250 & $989,662,500$ & 87.970 & 15,000 & $1,319,550,000$ \\
\hline $\begin{array}{l}\text { Saved cost } \\
\text { of treatment }\end{array}$ & 0.747 & $3,195,000$ & $2,386,665$ & 0.747 & $\begin{array}{r}3,195,00 \\
0\end{array}$ & 2,386,665 \\
\hline Costs & & & & & & \\
\hline $\begin{array}{l}\text { Distribution } \\
\text { of ITN }\end{array}$ & 6.7 & $3,678,756$ & $24,647,668$ & 6.7 & $\begin{array}{r}3,678,75 \\
6\end{array}$ & $24,647,668$ \\
\hline Gross margins & & & $967,401,497$ & & & $1,297,288,997$ \\
\hline
\end{tabular}

Table 12. Baseline scenario without adaptation and scenario with adaptation, using VOSL 


\begin{tabular}{|c|c|c|c|c|}
\hline Climate & $\begin{array}{l}\text { Development } \\
\text { indicators } \\
\text { - CC }\end{array}$ & $\begin{array}{l}\text { Development } \\
\text { indicators + CC }\end{array}$ & $\begin{array}{l}\text { Development } \\
\text { indicators }+ \\
\text { adaptation policies }\end{array}$ & Coping Strategies \\
\hline
\end{tabular}

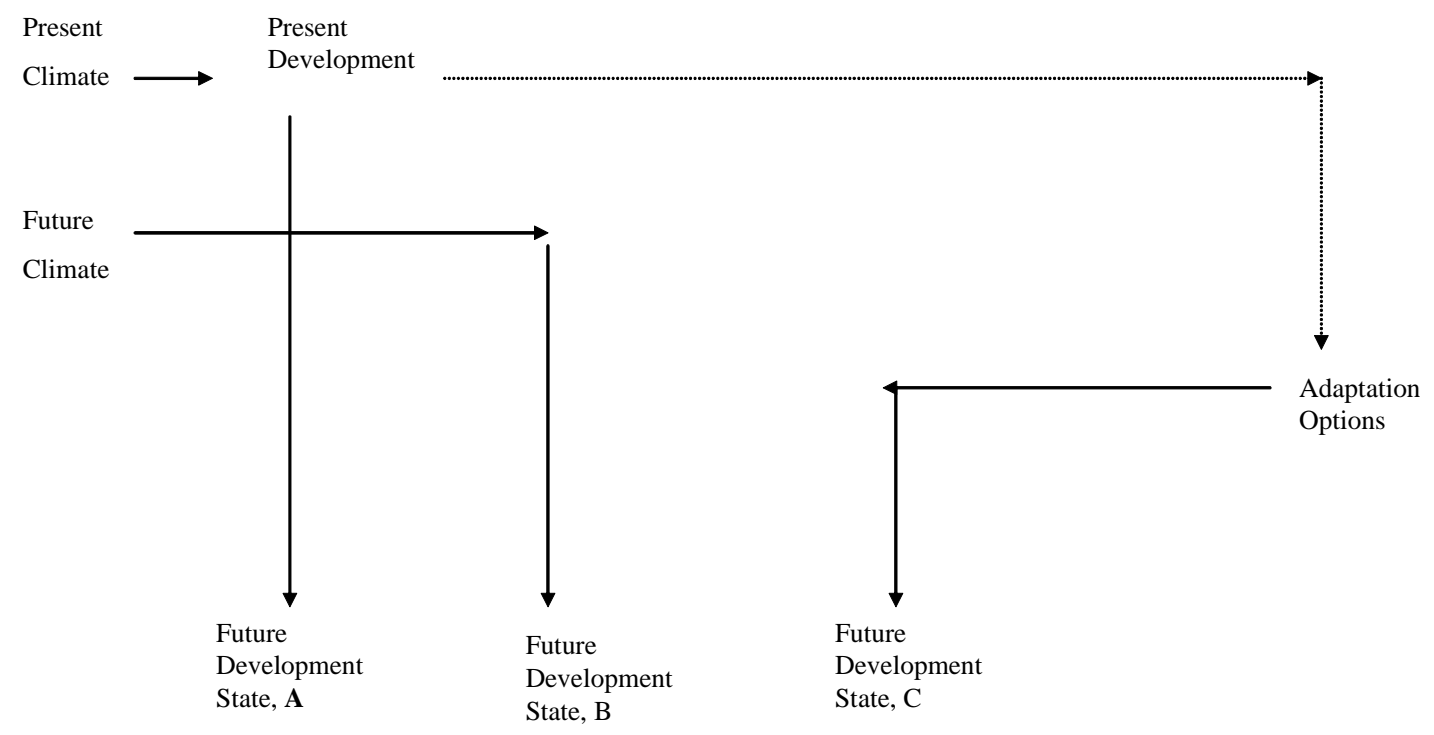

Figure 1. Structure for Assessing Development, Climate Change, and Adaptation Relationships 


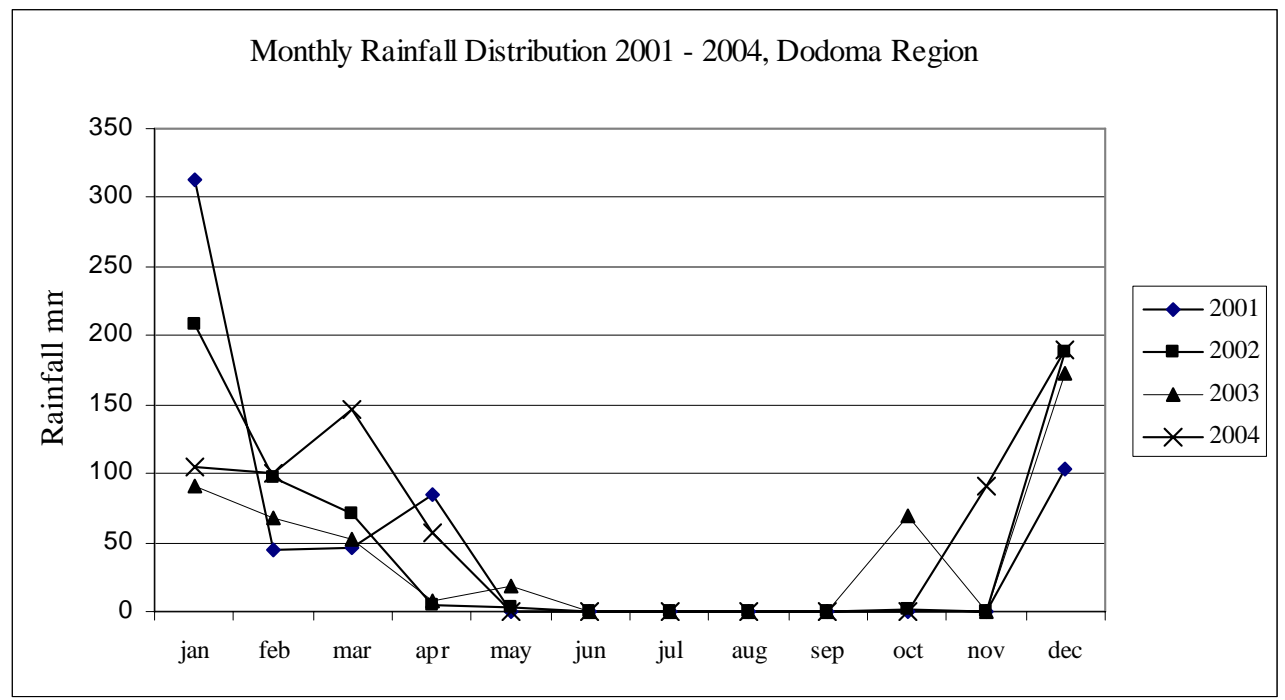

Figure 2. Monthly rainfalls from 2001 to 2004 in the Dodoma Region, Tanzania (Tanzania Meteorological Agency 2006) 